\title{
EXTERNAL SEX BRAND MORPHOLOGY OF \\ THREE SULPHUR BUTTERFLIES \\ (LEPIDOPTERA:PIERIDAE)*
}

\author{
BY RICHARD S. VETTER \\ AND \\ RONALD L. RUTOWSKI \\ Department of Zoology \\ Arizona State University \\ Tempe, Arizona 85281
}

\section{INTRODUCTION}

Males of many pierid butterflies have specialized scales, in patches or scattered over the wing surface, that are thought to be involved in the dissemination of a chemical signal (Chapman, 1971). Recent experiments with two sulphurs, Eurema lisa Boisduval and Leconte and Colias philodice Latreille, have borne out this assumption (Rutowski 1977, 1979). In these species, the male has a patch of cells and scales in the friction area of either the ventral forewing $(E$. lisa) or the dorsal hindwing ( $C$. philodice) that produces a chemical signal used to seduce females during successful courtship. Females respond to the chemical signal by extending the abdomen ventrally out from between the hindwings, thereby permitting copulation.

In many sulphur butterflies the males' sex brands are much more distinctive than those found in $E$. lisa and $C$. philodice. It is the purpose of this report to document the external morphology of the male sex brands of three species of pierids, Nathalis iole Boisduval, Eurema nicippe Cramer, and Colias cesonia Stoll, (Figure 1A). These species were chosen for two reasons: 1) they appear to represent a range of sex brand morphologies typical of that found in the pierid tribe, Coliadini (sulphurs), and 2) they have close affinities to species for which the function of the sex brand is welldocumented. A special effort will be made to understand the possible adaptive significance of this variation in sex brand structure.

*Manuscript received by the editor February 16, 1979. 


\section{METhODS AND MATERIALS}

All specimens were collected in Arizona between $17 \mathrm{July}$ and 16 September 1978. The dainty sulphur, $N$. iole, was collected at Clint's Well, the sleepy orange, E. nicippe, near Rye, and the dog face, $C$. cesonia, near Tortilla Flat. In addition, $N$. iole was reared through several generations in a greenhouse on the Arizona State University campus, Tempe, Arizona, on their natural foodplant, the tickseed (Coreopsis cardaminefolia Torrey and Gray or C. atkinsonia Douglas). To assess the effect of age on sex brand color or condition in $N$. iole and E. nicippe, individual males were assigned to one of three age classes on the basis of wing condition and scale loss: 1) fresh no noticeable scale loss or wing tattering, 2) slightly worn - visible scale loss and some tattering, especially along wing margins, and 3) worn - substantial scale loss and/or wings with deep nicks and tears. The categories used to describe sex brand color variation are presented in the results. Sex brand condition in $N$. iole was also a function of scale number and morphology. Scales in the sex brand were scored for whether or not they were present and, if so, whether they were flat, withered, or between these two extremes (half withered). Lab-reared males were examined on the day they eclosed; wild males were examined either alive or within 6 hours after they had died.

Changes in sex brand color with time since death were documented for $N$. iole. The wings of 16 freezer-killed males were stored in glassine envelopes at room temperature and the coloration of their sex brands scored at weekly intervals until all attained the final pale yellow color.

Wings of all three species were mounted on aluminium pegs with $\mathrm{Dag}^{\mathrm{R}}$, coated with gold in a D. C. sputterer for 3 minutes, and examined with an AMR-1000A scanning electron microscope at 20 $\mathrm{KeV}$ accelerating voltage. In some cases severe charging of the specimens necessitated longer coating times or low accelerating voltages $(5 \mathrm{KeV})$. All sex brands viewed with the SEM were from either freshly-killed males, live males, or males killed and stored at $-5^{\circ} \mathrm{C}$. To minimize the effects of desiccation at high vacuum some $N$. iole wings were dehydrated in ethanol, and passed through Freon-113 before critical point drying using Freon-13 as the transition fluid.

Scale densities were estimated for the sex brand and discal areas of the wings from scanning electron micrographs of wings whose 


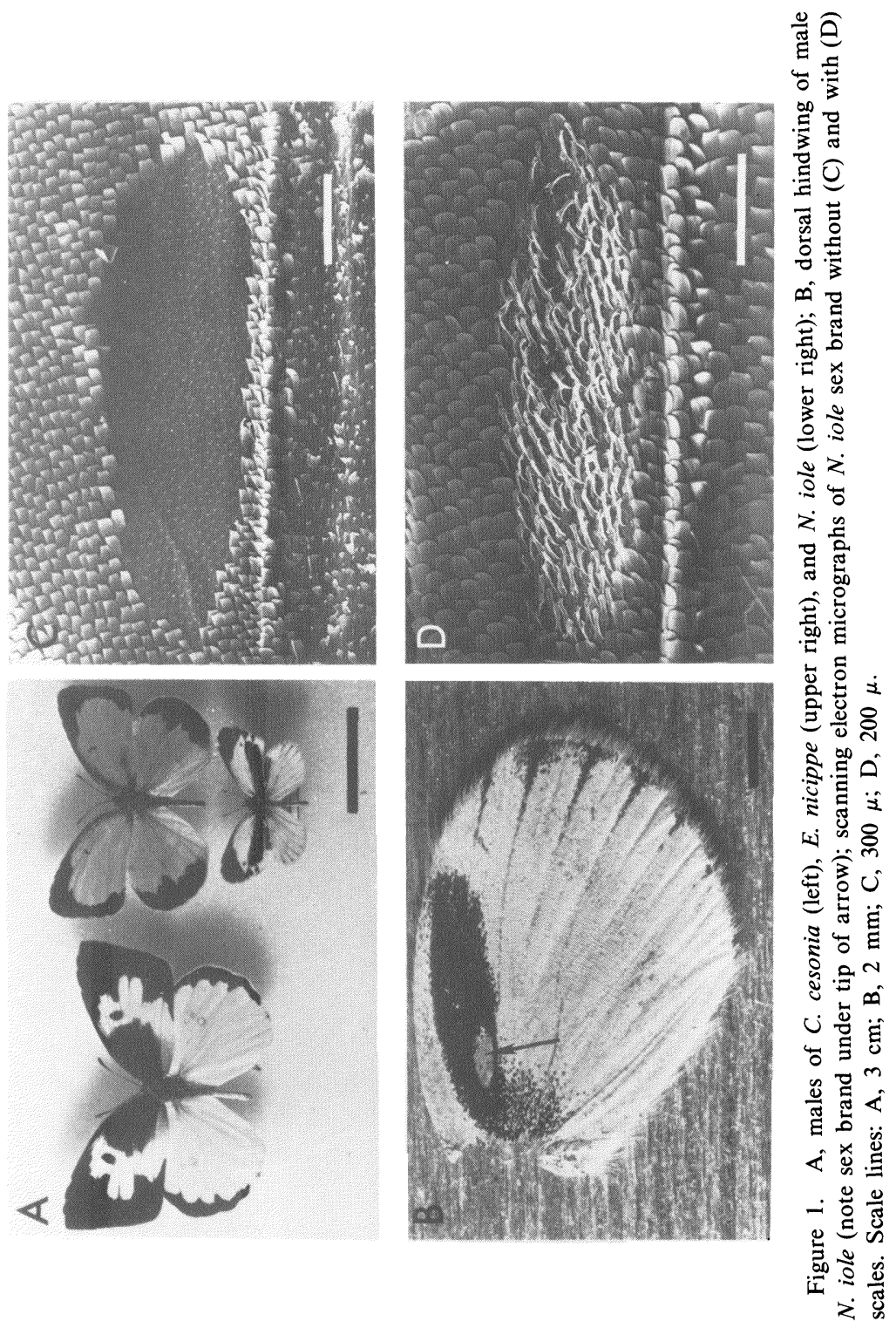


Table 1. The relationship between sex brand color in $N$. iole and several variables.

\begin{tabular}{cccccc} 
& \multicolumn{4}{c}{$\%$ of observations } & \\
\cline { 2 - 5 } Variable & $\begin{array}{c}\text { Dark } \\
\text { orange }\end{array}$ & $\begin{array}{c}\text { Light } \\
\text { orange }\end{array}$ & Mottled & $\begin{array}{c}\text { Pale } \\
\text { yellow }\end{array}$ & $\begin{array}{c}\text { No. } \\
\text { males }\end{array}$ \\
\hline Days since death & & & & & \\
3 & 88 & 0 & 6 & 6 & 16 \\
10 & 38 & 50 & 6 & 6 & 16 \\
17 & 6 & 56 & 25 & 13 & 16 \\
24 & 6 & 44 & 31 & 19 & 16 \\
31 & 0 & 6 & 31 & 62 & 16 \\
38 & 0 & 0 & 0 & 100 & 16 \\
& & $\chi^{2}=107.6, p<0.0001$ & &
\end{tabular}

Wing condition/age

fresh

$\begin{array}{rrrrr}94 & 4 & 2 & 0 & 48 \\ 71 & 29 & 0 & 0 & 17 \\ 57 & 21 & 11 & 11 & 28\end{array}$

Scales in sex brand

present

absent

$\begin{array}{lccrc}82 & 13 & 3 & 1 & 76.5^{\mathrm{a}} \\ 61 & 18 & 9 & 12 & 16.5^{\mathrm{a}}\end{array}$

Condition of scales in sex brand

$\begin{array}{lccccc}\text { shrivelled } & 82 & 13 & 5 & 0 & 38 \\ \text { half-shrivelled } & 81 & 11 & 0 & 7 & 13.5^{\mathrm{a}} \\ \text { flat } & 86 & 14 & 0 & 0 & 25.5^{\mathrm{a}} \\ & & \chi^{2}=6.85, \mathrm{p}>0.3 & & \end{array}$

a Fractional values indicates a male whose sex brands differed with respect to this variable.

scales had been removed with a small brush. The area of the wing represented in each micrograph was corrected for the fact that all specimens were photographed from an angle of $45^{\circ}$. Scale attachments intersecting the bottom and left hand borders of each micrograph were tallied while those intersecting the top and right hand borders were not. This procedure reduced the possibility of inflated density estimates.

RESULTS

The sex brand of $N$. iole

Males of $N$. iole have an orange, ovoid sex brand (about $0.5 \times 1.5$ $\mathrm{mm}$ ) on each hindwing between the subcostal and the radius veins near the wing base (Figure 1B). The brand is surrounded by a bar of 
melanic scales that runs along the leading edge of the hindwing from the wing base to the outer margin. The most unique aspect of the sex brand in $N$. iole is that it is frequently devoid of scales (Table 1 , Figure 1C). This condition is not a result of wear as it occurs in many newly-emerged lab-reared males (Table 2). When scales are present in the sex brand (Figure 1D) they may cover up to $100 \%$ of the brand and vary in form from a scale that is tan, flat, and similar to other scales on the wing to one that is black, shrivelled, and contorted (Figure 2A-C; Table 2). Within an individual male the form of the sex brand scales and the extent to which they cover each sex brand is usually uniform.

Scale attachments in the sex brand differ from those on other areas of the wing in appearance and in density. Unlike those in other areas, a typical sex brand scale attachment has fewer ridges running up its side, is more rounded, and has a pronounced swelling or bulge immediately behind the opening of the attachment (compare Figure 2C and D). This bulge is distinctly collapsed in air dried specimens compared with those that are critical point dried. The density of scale attachments in the sex brand is almost twice that of scale attachments in the immediately adjacent discal cell of the wing (Table 3; $\mathrm{t}=40.4, \mathrm{p}<0.001 ; \mathrm{df}=7$ ).

Examination of descaled wings or wings whose scales had been cleared in a dilute solution of sodium hypochlorite reveals that the color of the sex brand in live males is due to an orange pigment in the integument of the wing. This orange pigment typically extends little if at all beyond the edges of the sex brand. The pigment is visible under the light microscope in the space between the dorsal and ventral surfaces of wings that were crudely sectioned with a razor blade. Scanning electron microscopy of these same preparations reveals an ill-defined matrix of material, probably pigment, in this space that is restricted to the sex brand (Figures 2E and F).

As pointed out by Clench (1976) the orange color changes to pale yellow after the death of the butterfly. The complete transition takes about 6 weeks (Table 1) and does not occur at a uniform rate throughout the sex brand. Splotches of orange pigment remain in some areas while others have changed to yellow ("mottled"). We also made the unexpected observation that sex brand color changes with male age (Table 1). All newly-emerged, lab-reared males $(\mathrm{n}=$ 52) have dark orange sex brands while older males, as evidenced by wing condition, have significantly higher frequencies of mottled and yellow sez. brands (Table 1). 
Table 2. Differences between lab-reared and wild males of $N$. iole with respect to the presence and condition of scales in the sex brand.

\begin{tabular}{|c|c|c|c|c|}
\hline \multirow[b]{2}{*}{ Scales in sex brand } & \multicolumn{2}{|r|}{ Lab-reared } & \multicolumn{2}{|r|}{ Wild } \\
\hline & $\%$ & No. observed & $\%$ & No. observed \\
\hline \multirow[t]{2}{*}{ present } & 67 & & 82 & \\
\hline & & 52 & & 95 \\
\hline \multirow[t]{2}{*}{ absent } & 33 & & 18 & \\
\hline & \multicolumn{4}{|c|}{$\chi^{2}=3.81, p>0.05$} \\
\hline withered & 53 & & 49 & \\
\hline half-withered & 23 & 35 & 18 & 77 \\
\hline \multirow[t]{2}{*}{ flat } & 24 & & 33 & \\
\hline & \multicolumn{4}{|c|}{$\chi^{2}=1.03, p>0.4$} \\
\hline
\end{tabular}

The sex brand of E. nicippe

In E. nicippe, the sex brand appears as an orange, triangular patch of scales about $3 \mathrm{~mm}$ across on the ventral surface of each forewing between the second branch of the cubitus and the second anal vein (Figure 3A). The scales in the brand are typically brilliant orange in color in contrast with the white to light-orange scales that surround the brand. Orange pigment extends through the base of each scale in the wing integument where it can be seen as an amorphous blob underlying each scale attachment in the sex brand. Unlike that of $N$. iole, the sex brand of E. nicippe is always covered with scales that occur at about twice the density of scales in the discal cell of the ventral forewing (Table $3 ; \mathrm{t}=78.4, \mathrm{p}<0.001$, $\mathrm{df}=7$ ).

The scales in the sex brand and their attachments are quite different in form from those found on other areas of the wings (Figures $3 \mathrm{~B}$ and $\mathrm{C})$. The scales are shorter $(60 \mu \mathrm{m}$ as compared to $80 \mu \mathrm{m}$ for scales in discal cell) and they extend from the wing surface at a greater angle. Other differences in scale shape are evident in Figures $3 \mathrm{~B}$ and $\mathrm{C}$. The sex brand scale attachments are much larger than those in the discal area of the wing and as in $N$. iole have a pronounced bulge or swelling behind the opening.

The orange color of the sex brand is not constant in all specimens (Table 4). Older specimens, as measured by wing wear, typically have a bright white sex brand. In males in intermediate ages, one often finds an intermediate coloration, with the upper half of the sex 
brand white in color and the lower half a light orange. The sex brand color does not change with death.

\section{The sex brand of Colias cesonia}

Colias cesonia males have a sex brand on the dorsal hindwing between the subcosta and radius veins near the wing base (Figure $3 \mathrm{D})$. The color of the brand ranges from lemon yellow to a light yellow with no consistent changes with age or death that we have observed. The color is solely attributible to the scales as the
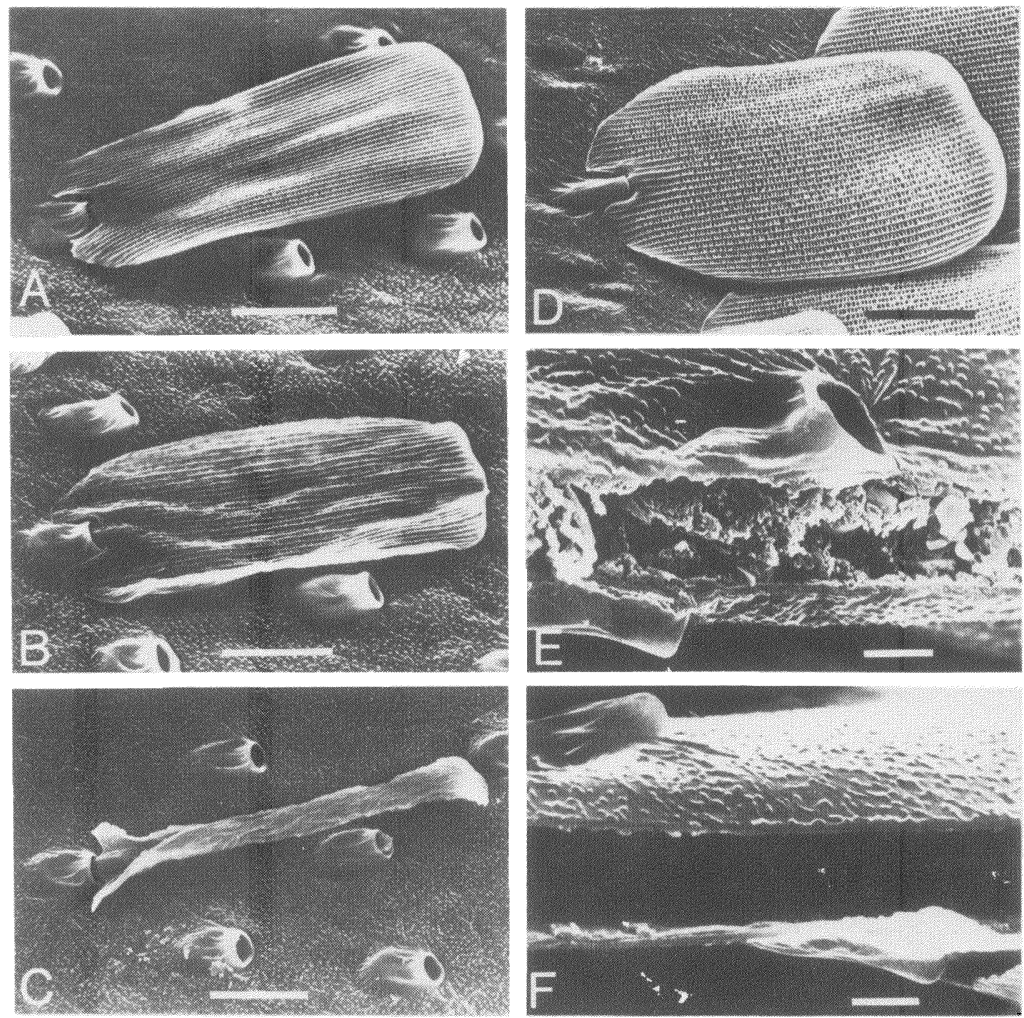

Figure 2. Scanning electron micrographs of $N$. iole wings. A-C, variation in the structure of sex brand scales; D, a scale from the discal cell; E, crude cross section through the sex brand showing pigment between the dorsal and ventral wing surfaces; F, crude cross section of the wings in the discal cell. See text for details. Scale lines: A-D, $20 \mu ; \mathrm{E}$ and $\mathrm{F}, 5 \mu$. 



Figure 3. Eurema nicippe: A, male ventral forewing (note sex brand under tip of arrow); scanning electron micrographs of male scales from the sex brand (B) and the discal cell (C). Colias cesonia: D, male dorsal hindwing (note sex brand under tip of arrow); scanning electron micrographs of male scales from the sex brand (E) and the

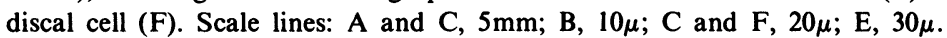

integument of the wing under the scales is clear. The scales surrounding the sex brand are of a color similar to that of the brand. However the sex brand is still distinct from the rest of the wing in that the density of scales is twice as high (Table $3 ; \mathrm{t}=42.9, \mathrm{p}<$ $0.001, \mathrm{df}=4)$. In fact, the scales in the brand are almost perpendicular to the wing surface.

The scales are also unique in form (Figures $3 E$ and $F$ ). In particular, the pedicel of each scale arises from the surface of the scale against the wing rather than projecting from the base in the 
same plane as the scale. The base of each scale in the sex brand extends beyond the point where the pedicel emerges and partially overlies the scale socket on the wing surface. The spacing of the longitudinal and transverse ridges on these scales also appears more variable than it is on other types of scales.

\section{Discussion}

Detailed information is now available about the sex brand morphology of five species of sulphur butterflies in the pierid tribe, Coliadini. They include Eurema lisa (Rutowski, 1977) and Colias philodice (Rutowski, 1979) as well as the three species discussed in this report. Several generalizations have appeared.

1) All male sex brands are located in the friction areas of the wings, that is, the area of overlap between the forewings and hindwings. Rutowski (1979) has suggested that this placement of the sex brand helps to minimize evaporation from an otherwise exposed and non-eversible scent producing structure.

2) The scales observed in the sex brand are not greatly differentiated from those found in other areas of the wings. This contrasts with the scent scales found in many eversible scentproducing organs that are very hair-like (e.g. danaids (Pliske and Salpeter, 1971), noctuids (Birch, 1970)) and with the presumed scent scales on the wings of some pierids and nymphalids which have fringed distal borders (Barth, 1950; Bergström and Lundgren 1973; Tinbergen et al., 1942).

3) The scales are associated with cells in the integument of the wing that reside in a swelling in the wing immediately behind the scale socket. Presumably these cells are secretory trichogen cells like those found in scent-producing structures that are histologically better known, (e.g. danaids (Pliske and Salpeter, 1971)).

These similarities reflect not only the phylogenetic affinities of these species but also the action of similar selection pressures. The behavior of the male during courtship is similar in all five species. The male buffets the female with his wings while she flies or perches on vegetation (Rutowski, 1978; Silberglied and Taylor, 1978; pers. obs.). Selection has not acted to favor any divergence from this pattern among these species and hence there have been no major 
Table 3. Scale attachment densities for the wings of three pierid butterflies.

\begin{tabular}{|c|c|c|c|c|c|c|}
\hline \multirow[b]{2}{*}{ Species } & \multirow[b]{2}{*}{ Area } & \multicolumn{2}{|c|}{ Attachments $/ \mathrm{mm}^{2}$} & \multicolumn{2}{|c|}{ Area/sample $\left(\mathrm{mm}^{2}\right)$} & \multirow{2}{*}{$\begin{array}{c}\text { Sample } \\
\text { size }\end{array}$} \\
\hline & & $\overline{\mathrm{X}}$ & SD & $\overline{\mathrm{X}}$ & SD & \\
\hline \multirow[t]{2}{*}{ N. iole } & sex brand & 662.9 & 156.9 & 0.050 & 0.003 & 5 \\
\hline & discal cell & 393.1 & 22.4 & 0.144 & 0.106 & 4 \\
\hline \multirow[t]{2}{*}{ E. nicippe } & sex brand & 974.3 & 142.2 & 0.048 & 0.003 & 5 \\
\hline & discal cell & 427.2 & 63.2 & 0.234 & 0.031 & 4 \\
\hline \multirow[t]{2}{*}{ C. cesonia } & sex brand & 411.3 & 40.5 & 0.231 & 0.012 & 3 \\
\hline & discal cell & 216.3 & 21.1 & 0.216 & 0.016 & 3 \\
\hline
\end{tabular}

changes in the basic structure of the sex brands. Still, there are some striking differences in their fine structure for which there is no ready explanation. These differences include: 1) placement of sex brand (forewing vs. hindwing), 2) scale density (some species have sex brands in which there is no apparent increase in sex scale density compared to surrounding areas), 3) presence or absence of scales in the sex brand, and 4) changes in color with male age or death. The biological rationale for these differences will have to await more detailed information on the chemistry and cellular structure of these sex brands.

This study was supported by funds from NSF Grant BNS 78-11211 and an Arizona State University Faculty Grant-in-Aid, both to R. L. Rutowski. We thank Dr. D. J. Pinkava for identification of plant specimens and Mr. L. Marshall for helpful comments on the manuscript.

Table 4. The relationship between sex brand color and wing condition in E. nicippe.

Sex brand color (no. of males)

\begin{tabular}{lccc}
\cline { 2 - 4 } Wing & Orange & $\begin{array}{c}\text { Half orange, } \\
\text { Half white }\end{array}$ & White \\
\hline Fresh & 6 & 14 & 3 \\
Worn & 0 & 3 & 9 \\
Very worn & 0 & 0 & 5 \\
& & $\chi^{2}=20.8, \mathrm{p}<0.0005$
\end{tabular}




\section{REFERENCES}

BARTH, R. H.

1950. Vergleichend morphologische Studien über die Duftschuppen der Pieriden Pieris brassicae und Pieris rapae und der Satyrine Coenonympha pamphilus. Zool. Jahrb. (Anatomie) 70: 397-426.

Bergström, G. and L. Lundgren.

1973. Androconial secretion of three species of butterflies of the genus Pieris (Lep., Pieridae). ZOON Suppl. 1: 67-75.

BIRCH, M. C.

1970. Structure and function of the pheromone-producing brush-organs in males of Phlogophora meticulosa (L.) (Lepidoptera: Noctuidae). Trans. R. ent. Soc. Lond. 122: 277-292.

Chapman, R. F.

1971. The Insects: Structure and Function. American Elsevier, New York. Clench, H. K.

1976. Fugitive color in the males of certain Pieridae. J. Lep. Soc. 30: 88-90.

Pliske, T. E. AND M. M. Salpeter

1971. The structure and development of the hairpencil glands in males of the queen butterfly, Danaus gilippus berenice. J. Morph. 134: 215-242.

RUTOWski, R. L.

1977. Chemical communication in the courtship of the small sulphur butterfly, Eurema lisa (Lepidoptera, Pieridae). J. comp. Physiol. 115: 75-85.

1978. The courtship behaviour of the small sulphur butterfly, Eurema lisa (Lepidoptera: Pieridae). Anim. Behav. 26: 892-903.

1979. Male scent-producing structures in Colias butterflies: Function, localization, and adaptive features. J. Chem. Ecol., in press.

Silberglied, R. E. and O. R. TAylor, JR.

1978. Ultraviolet reflection and its behavioral role in the courtship of the sulphur butterflies Colias eurytheme and C. philodice (Lepidoptera, Pieridae). Behav. Ecol. Sociobiol. 3: 203-243.

Tinbergen, N., B. J. D. Meeuse, L. K. Boersma, and W. W. Varossieau.

1942. Die Balz des Samtfalters, Eumenis (=Satyrus) semele (L.) Z. Tierpsychol. 5: 182-226. 

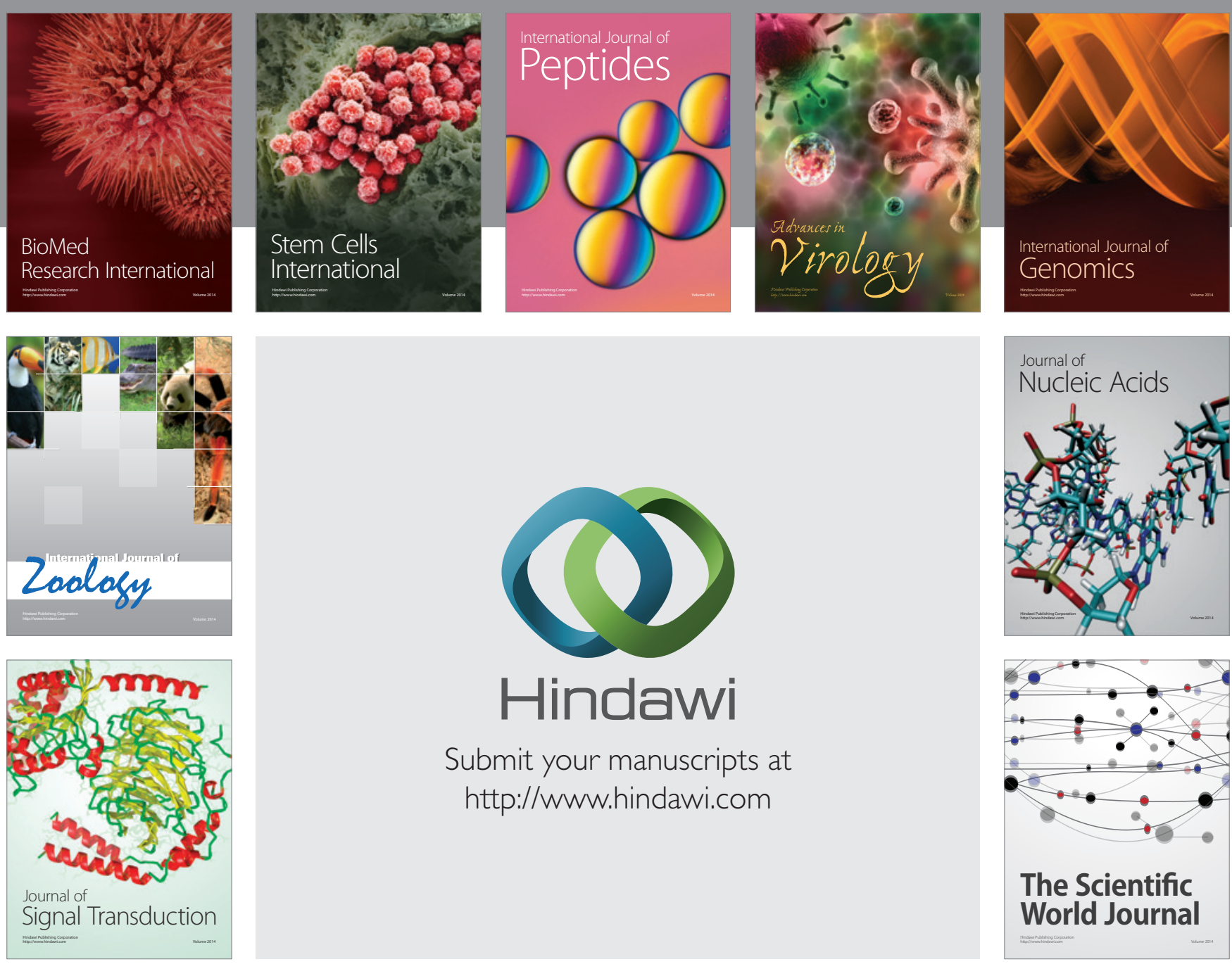

Submit your manuscripts at

http://www.hindawi.com
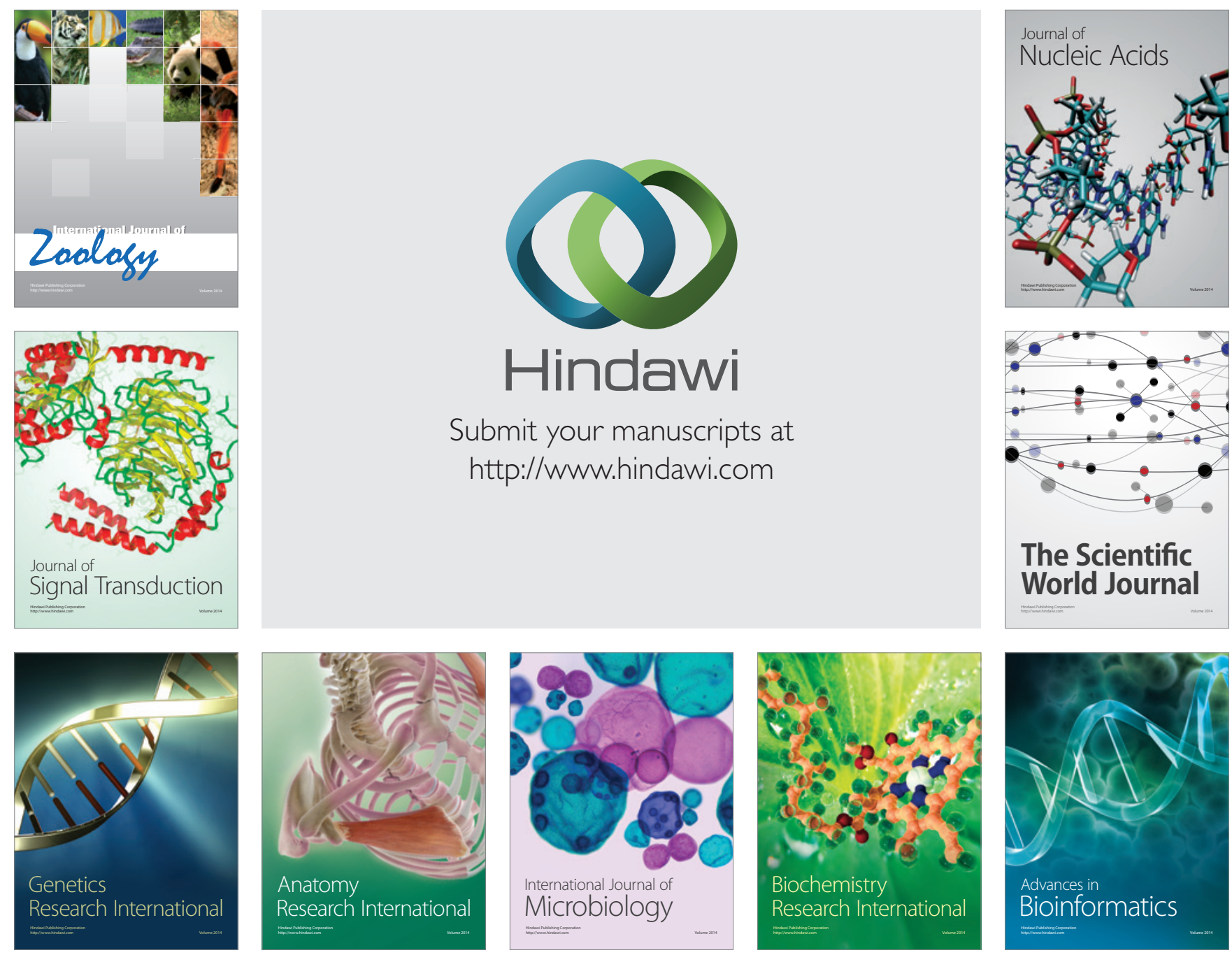

The Scientific World Journal
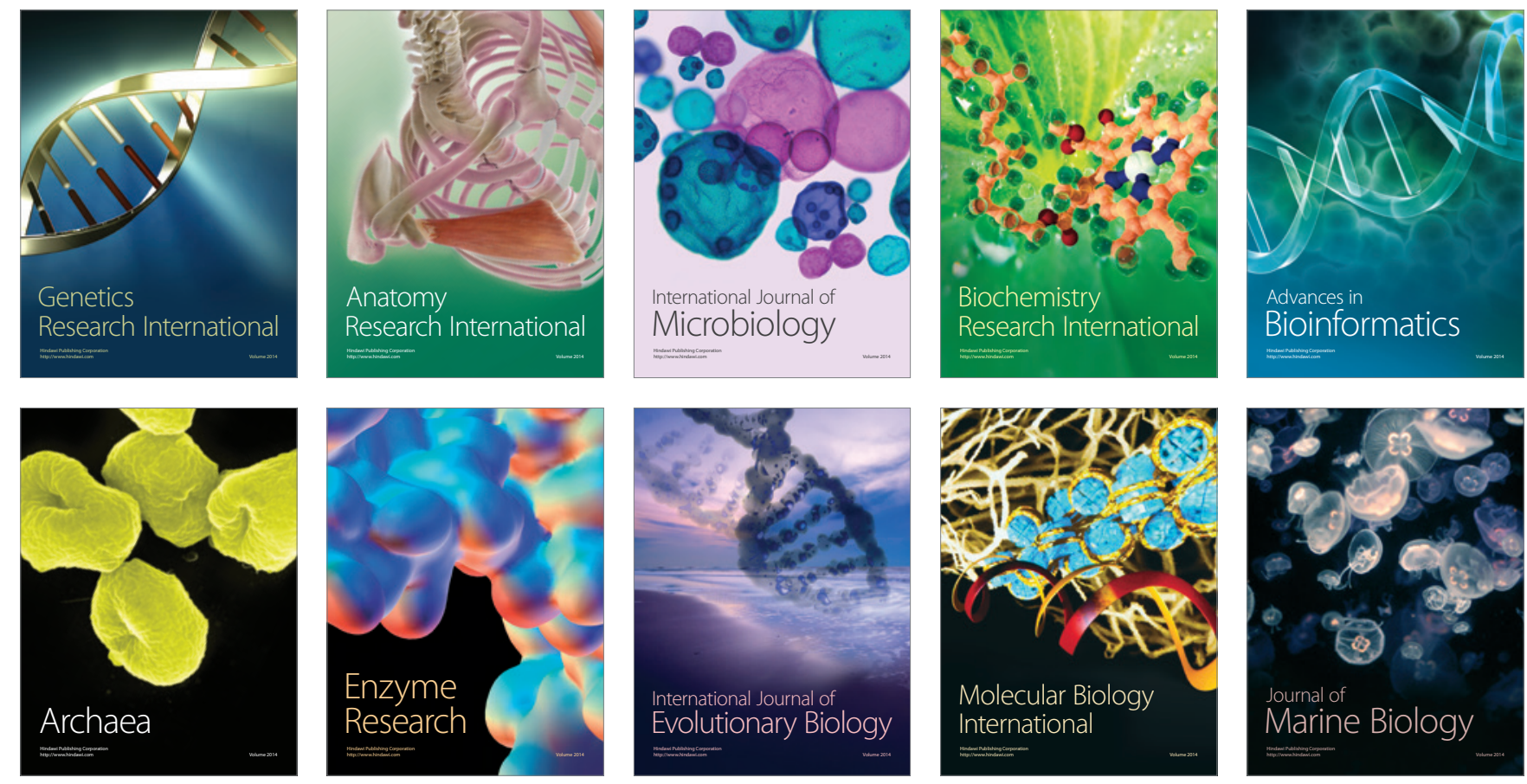